\title{
50 年前の学生の見た蛋白質結晶学発展の歴史
}

\author{
北海道大学名誉教授 田中 勲
}

\begin{abstract}
Isao TANAKA: The History of Protein Crystallography Witnessed by a Student 50 Years Ago
Protein crystallography is a field of science that has significantly developed in the last halfcentury. However, its amazing development has not been straightforward and has gone through many trials and errors. In this paper, we recall historical fragments of protein crystallography in the last halfcentury that are thought to be important for the author and are likely to be buried in its spectacular history.
\end{abstract}

\section{1. はじめに}

結晶学会から 70 周年記念特集号の「歴史編」として結 晶学の発展を振り返る原稿を依頼されたとき,「少し古 い時代の歴史なら」と断わった後に執筆させていただく ことにした. 本稿は, 50 年前に学生だった私たちの世代 が見た, 蛋白質結晶学の類いまれな発展の歴史の断片で ある. 50 年は蛋白質結晶学をすっかり变えてしまうほど 十分長い年月だった，今日この分野に入ってきた学生に とっては, この高度に発達した蛋白質結晶学の状態があ たりまえのスタート点となるわけである，その学生がこ れからの半世紀を科学者として過ごすときに, これまで の半世紀の出来事が役に立つかどうかはわからない．似 たような出来事は起こらないだろう，それでも「何らか の参考になれば」と思いながら作業を進めた。誌面が制 限されている中での作業である. 当然ながら, 私の主観 が扔打いに入っていることを最初に扮断りしておく.

\section{50 年前の大学の研究室}

今となっては, 自分がなぜこの分野に進むことを決 めたのか漠然とした記憶しかない. 1970年代のはじめ, 大阪大学理学部化学科で 4 年生になる頃, いわゆる講座 配属ということで, どこかの研究室を選ぶ必要に迫られ た. 研究室配属のための講座訪問の1つとして蛋白質研 究所の角戸正夫先生の研究室を訪れ, 日本で最初の蛋 白質立体構造解析を目指しているという先生の説明の, おそらくは「日本で最初の」というところに魅かれたの だと思う，特に将来に対する展望や計算があったわけで はない，もち万ん，この分野がその後大発展を遂げると は想像もしなかった。いつかは自分も1つの蛋白質の立 体構造を決めたいという思いだけは間違いなくあった。

角戸研究室には, 当時の最先端の装置, 4 軸自動回折 計があった。紙テープに刻まれたプログラムを読み込め
ば, 自動的に回折の起こる角度を計算し，装置をその位 置に持って行って, 回折強度を計測してプリントアウト するという, 現在なら何の変哲もない装置だが, はじめ て見るその自動装置にとても感動した。 国内初の蛋白質 構造解析を目指している角戸研究室は, 大型計算機セン ターの最大のユーザーグループの1つでもあった．しか し，その計算機を使うためには，1枚のカードに1行の Fortran プログラムをパンチしたカードの束を, 同じよ うにカードにパンチしたデータの束とともに, 大きな箱 に詰めて計算機センターに持って行く必要があった。 蛋 白研があった大阪中の島から豊中の計算機センターに カードを送って, その結果が帰ってくるまで約 1 週間。 プログラミングエラーで返ってきたら 1 週間が無駄にな るので, 皆, 非常に気を遣った。

そんな時代, 乏しい知識を駆使して解析のためのプロ グラムを作ること，あるいは4軸回折計をコントロール するプログラムを密かに解読することなど, 学生の私に とっては至福の時間だった，修士論文を手書きで仕上 げるのはずいぶん大変だったが, パソコンが使える現 代の学生を羡ましく思う反面, 考える時間も遊ぶ時間も たっぷりあった当時の状態を懷かしく思う。

\section{50 年前の蛋白質結晶学}

当時, 立体構造が解明されていた蛋白質は, へモグロ ビン，ミオグロビン，リゾチームなど数える程しかな かった. 大量発現系などない時代, 当然, 自然界に大量 に存在する蛋白質のみが研究対象となりえた. 蛋白質研 究所では, かつ扮のチトクロームCの解析が進められて いた。

蛋白質結晶学は, 多くのサイエンスの中でも, この半 世紀で特に著しく発展した分野であると言えるだろう。 解析される蛋白質の数は指数関数的に増加していった。 したがって解析された蛋白質の数を年ごとにプロット 
すれば, 80 年代より前に解析された蛋白質の数は, ほと んどゼロに等しいような状態になってしまう. 実際, 70 年代には, 蛋白質構造解析の論文は, J. Mol. Biol.のよう な生化学雑誌の中に, ほかの多くの論文に混ざって, ご くたまに見られる程度だった。一般の生化学者にとって は, 蛋白質の構造解析は進渉があまりに遅すぎて, 共同 研究を始めるのを躊躇するような科学だったと思う.

結晶学を学び始めてすぐに, 結晶学には「位相問題」 という難問があることを知った。しかし，蛋白質結晶に ついては, へモグロビン，ミオグロビンの解析で, 同形 置換法が使えることが示されていた，結晶の中に重原子 が染み込んで特定の位置に固定されるという，ありそう もない現象を利用して, 実際にへモグロビン, ミオグロ ビンの構造が解かれたのだ，そんな画期的な話を聞いた とき，そして，低分子でさえそれ以上にすばらしい解析 法はないときに，それ以上のやり方で, 何万とある反射 の位相を決めるための方法があるとは，あるいはそれを 探そうとは, 夢にも思わなかった. 蛋白質構造解析研究 者のやるべきことは, ひたすら有効な同形置換体を探す ことだと思っていた。

\section{4. 結晶化装置の発展}

今日の蛋白質結晶学の隆盛を支えている技術の 1 つに 蛋白質の大量発現技術があるのは疑いもない事実である が, 同時に, 微量結晶化技術の発展も大きい. 50 年前に 研究室で教えてもらった蛋白質の結晶化法は, 試験管の 中の蛋白質溶液に硫酸アンモニウムを少しずつ溶かし ていき, 白濁させた溶液の中から結晶が成長するのを待 つ，今で言うバルク法であった。何年か後, カバーグラ スに液滴をぶら下げるハンギングドロップ法のアイデア を知ったときには感動した

蛋白質の結晶化の成功率を飛躍的に高めたのは, 90 年代はじめに出現した結晶化溶液キットである。実績の ある結晶化溶液組成の組み合わせを商品化したものであ るが, 今では多くの商品が生まれており, 最初に試すべ き手段となっている.結晶化がたくさんの条件を試す試 行錯誤実験であることから，当然の帰結なのかもしれな いが, データベースを作ることの重要性を知らされた。 結晶化キットのその後の発展は, サイエンスの勝利とい うよりもべンチャービジネスの勝利のように思える.

近年は, 微量の溶液を使って結晶化するロボット化 した装置が出回っているが, ここでは故渡邊信久氏と取 り組んだ結晶化チップについて少し触れたい，振興調整 費の萌芽研究に採択され，ある企業と組んで 3 年間取り 組んだ、沈殿剂を染み込ませたゲルで満たした中空糸を 束にしてチップ化し，そこに蛋白質溶液を上から一滴落 とすだけで, 何十種類もの条件が一度に試せるという計 画だった. 3 年間の苦労の末に, 100 種類の結晶化溶液 日本結晶学会誌 第 62 巻 第3 号 $(2020)$

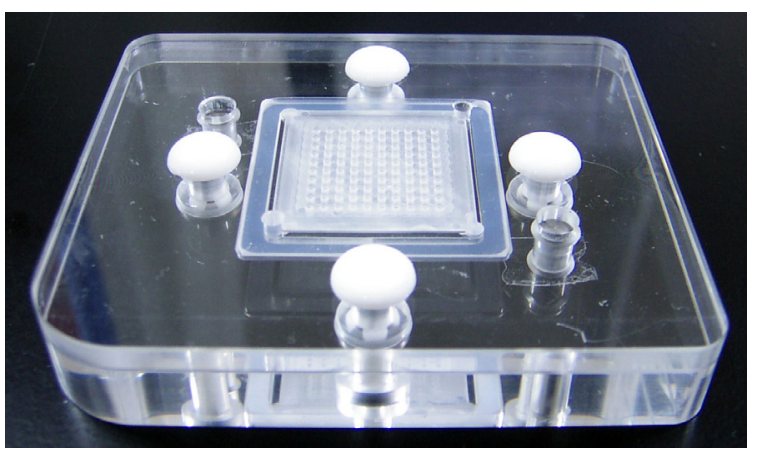

図1開発した結晶化チップ(2003). (Crystallization chip developed in 2003.)

を $2 \mathrm{~cm}$ 四方のチップに封じ込めることに成功し，世界初 の「蛋白質結晶化チップ」のプロトタイプ（1条件50ナ ノリットル，100条件のデバイス）を完成させた（図1). しかし, 評価委員会では, 実際に適用できた蛋白質がな いという理由から, あまり評価されず,このプロジェク トは終わってしまった，今でも，もう少し頑張れば実用 に足るものが生まれたのではないかとの心残りがある。

\section{5. 計算機環境の発展}

現代の学生は, 何の違和感もなくパソコンを使って蛋 白質の構造解析を行っているが, それはとてつもなくす ごいことで, 50 年前にはまったく予想もできなかった ことだ. 当時から計算機は着々と進歩していたので, 計 算機が速くなるだろうとの予感はあったのだが, 思い描 いていた未来は, 計算を依頼したらすぐに結果が返って 来る大型計算機であった. 70 年代の計算機センターに, 今で言う「端末」が設置され，それを使ってプログラム を書いたり計算を依頼したりすることができるように

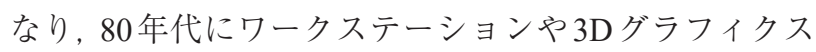
が出現し, 90 年代にはそれが普及して各研究室のもつコ ンピュータで解析ができるようになった.メールやイン ターネットが普及したのもその頃である。はじめて電子 メールが登場したときには, 便利であることに感激しな がらも，誰が扮金を払っているのか，その内に有料にな るのかと, もっぱら噂した、インターネットに至っては さらに驚きで，ほとんど自分の思考を超越しているとさ え感じた。

計算機の高速化はある程度予想されていたので, 50 年 前には蛋白質の構造はその内には計算で予測できるよう になるだろうと漠然と思っていた。しかし現時点でも， 蛋白質の立体構造をアミノ酸配列情報のみから計算で求 めることは依然として難しい，その一方で, 解析法が進 歩することに伴って, 蛋白質の基本構造の多くが決定さ れ，立体構造予測は既知の構造を参照することで信頼度 の高いものが得られるようになっている. 発展の順序が このようになるとは思いもかけなかった，もち万ん「蛋 
白質の構造は有限である」と言われる日が来ることも予 想していなかった。

\section{6. 蛋白質結晶学を変えた理論}

重原子同形置換法はネイティブの結晶と，それに重原 子を入れた重原子同形置換体の結晶の両方の回折強度 から重原子の位置を決め，それを基にネイティブ結晶の 位相を求める方法である，その理論を少しかじればすぐ にわかるように，ネイティブ結晶と同形置換体結晶は, 重原子が入っているということのほかには, 構造がまっ たく同じであることを前提としている. 蛋白質の構造は もちろんのこと, 結晶の周期性 (すなわち格子定数) が 変化してしまうと, その前提が崩れてしまう。しかし, 重原子を入れて, 格子定数が変化しないことなどほとん どありえない. 何とか近似的な同形置換結晶を得て, 位 相を計算して電子密度が得られたとしても, はじめから 蛋白質の鎖を追えるような電子密度が得られることは まずない，その段階で計算機を使ってやれることは，昔 は、ほとんどなかった。したがって,「その電子密度はひ とまず置いておき，次の重原子同形置換体を探す」，そん な状態がずっと続いていた，きれいな電子密度が得られ ない理由は, 非同形性から来る誤差, 重原子位置の不正 確さ, 回折強度測定の誤差などいろいろ考えられて,つ まりは,「蛋白質結晶学は誤差の大きい科学だから」と納 得するしかなかった，現在の知識で振り返れば，きれい な電子密度が得られなかった理由は，ほぼ間違いなく, 位相が不正確だったからであろう。

この状沉を変えたのは電子密度改良技術（あるいは 位相改良技術）である。きっかけとなった論文はB.C. Wangによるものである (B. C. Wang: Methods Enzymol. 115, 90-112 (1985)). そのアイデアは電子密度からノイズ を消去することから始まる，その方法は非常に簡単だが, この論文のもたらした影響を過小評価すべきではない． 当時, 非対称単位に複数の分子が含まれている場合, そ れらの分子の電子密度を重㸚わせることで電子密度が 飛躍的に改良されることはよく知られていた。しかし， その方法は一般性に欠けた，それに比べてB. C. Wangの 方法は, 分子領域と溶媒領域との境界を（客観的に）決 めた後, 分子領域で負の電子密度を与える部分をゼロに 置き換え, 溶媒領域は一定の大きさに (平滑に) するも のであり(これを合わせて noise filtering と呼んだ)，その 効果は小さかったが一般性があった，その電子密度を逆 フーリエ変換することで逆空間の位相改良につなぐ，こ うして実空間の電子密度改良と逆空間の位相改良を交 互に繰り返し行うことで, 一種の精密化サイクルを回す ことができた，この方法が成功を収めて以降, 電子密度 の改良法は, 最尤法も組込みながら, さまざまな新しい 方法が生み出されていき, これによって蛋白質結晶学は
変貌した。

同じ頃, 放射光が使えるようになってMetを Se-Metに 置き換えた蛋白質を使い, Seの吸収端前後の, 異常散 乱効果の異なるいくつかの波長で回折データを集めれ ば, 多重同形置換法と同じ原理で解析ができることが示 され (多波長異常散乱法：MAD法), その方法 (Se-MAD 法) が, 事実上, 蛋白質の汎用的解析法となるまでに, そ んなに時間はかからなかった. 実際, 圧倒的なスピード で解析例が増えていった（I. Tanaka: 日本結晶学会誌 57, 155-162 (2015)).

ところで, B. C. Wang の方法は, もともと単一同形置 換法 (SIR 法) や単波長異常散乱法 (SAD法) が, 理論上 もっている位相の ambiguity (正と偽の $2 つ の$ 解を区別で きないということ）を克服するための方法として発表さ れたものである，実際，位相改良技術を使えば，多波長 デー夕を集めるまでもなく, 単波長デー夕で構造が解け るということが徐々に認識されていった。 ビームライン やその他の実験手法が洗練されたこともあって, 2000 年代の中頃には, Se-SAD法がSe-MAD法に代わって汎 用法としての地位を占めるに至った. 異常散乱原子の吸 収端が通常のエネルギー領域から離れすぎているため にMAD法が使えないような場合でも，SAD法は適用で きる. 実際, 蛋白質に含まれる $\mathrm{S}$ (核酸の場合は $\mathrm{P}$ ) の異 常散乱を利用して解析が可能であることが示され，その 解析例も, 少しずつではあるが, 増えてきた。この方法 (S-SAD法) は, ネイティブ蛋白質の結晶をそのまま利用 できるので，そのことを強調して native-SAD法とも呼ば れる. 50 年前の学生が夢見た蛋白質構造解析法が現実 のものになろうとしている.

\section{7. 蛋白質回折データ収集法の変遷}

蛋白質結晶学の発展に最も大きく寄与したものを $1 つ$ 挙げるなら，それは，もちろん放射光となるだろう. 80 年代に第 2 世代の放射光施設ができ, 90 年代には挿入光 源を備えた第 3 世代の施設ができ, その度にX線は桁違 いに強くなった. 科学の世界では, 3 桁違えばイノベー ション (革命的変化) が起こるそうだが, X線の分野で は，それが少なくとも2 度起こったことになる，そのた びに結晶学は大きく変わったが, ここではX線源の発展 に伴って変わっていった回折光を記録する方法に焦点 をあてる。

先に書いたように, 1970年代初頭, 蛋白質研究所には 4 軸回折計が導入されていたが, これは日本の研究室で は例外的に恵まれた状態で,一般には，(低分子結晶の) 回折デー夕を収集するためには，X線フィルムを重ねて 使う多重フィルム法が使われていた。 シンチレーション カウンターを使った4軸自動回折計は, X線フィルム法 より圧倒的に感度が高い. しかし, 反射を 1 つずつ精度 
よくとっていくこの方法は, 低分子結晶のデー夕収集に は理想的であっても, 逆格子が密で, 時間とともに壊れ ていく蛋白質結晶にとっては, 必ずしも理想的とは言え なかった. 4 軸回折計の欠点は, 1 反射ずつしか記録でき ない非効率性と, 特に高角の反射では近傍の反射との分 離が難しいことにあった. X線フィルムは, 感度こそ落 ちるが, 二次元検出器として記録するので, 一度にたく さんの反射が記録でき，また近傍の反射と分離して記録 することも比較的易しい. 特に格子が大きい場合には, このメリットは大きかった。このため, 欧米では, 比較 的早い時点で, 蛋白質結晶の回折デー夕収集は, 一見, 前近代的な X線フィルムを使って行われるようになって いた。

80 年代半ばになって放射光が普及し, また巨大蛋白 質が解析の対象になってくると,4軸回折計の欠点はま すます鮮明になってきた，その頃になると日本でもよう やくX線フィルムへの回帰が始まった，特筆すべきは， 坂部カメラ（巨大ワイセンベルグカメラ）である. 坂部 知平先生設計の, この装置は, 結晶軸を立て, 多層スク リーンを入れてデータをとるように開発されたものだっ たが, 欧米でスクリーンレスでのデータ収集法を経験し た者たちは，坂部カメラを，スクリーンを入れずに使っ た、スクリーンを入れることのメリットは, 反射の重な りがなくなる，指数付けがしやすい，そしてもちろん， バックグラウンドが減少することにある。一方で, 効率 の面では, 結晶軸を立てずに, スクリーンレスで記録し たほうがずっとよい. 80 年代半ばに, 富士フイルムが医 療用に開発したイメージングプレート (IP) がX線回折 データ収集に使えることがわかると，坂部カメラにIPを マウントして, スクリーンレスで使うデー夕収集法が確 立した。この方法は, 日本で生まれた世界的なデー夕収 集技術として日本の蛋白質結晶学を牽引した。

一方, 世界的には, マルチワイヤ型の検出器, TV 型 検出器, $\mathrm{CCD}$ など, さまざまな検出器の開発が続けら れ, 現在の光子計数型検出器へと続く. IPの欠点は, $\mathrm{X}$ 線フィルムと同様, いったん蓄積したデー夕を後で読み
出すための時間を要することにある，第 3 世代の放射光 施設が建設され, 放射光がさらに高輝度になると, 読み 取りに時間がかかるIPが放射光で使われることはなく なった，またデー夕読み出しが高速になるにつれて，1 フレームの回転角は短くなっていった，第 3 世代放射光 の低エミッタンス特性とも相まって, S/Nは飛躍的に改 善され，極微小結晶を使ってのデー夕収集が可能になっ た. 1 フレームの回転角を短くすると, 部分反射が増え ることが問題とされた時代を知っている者にとっては隔 世の感がある。

\section{8. 消えていく歴史の断片}

この 50 年で蛋白質結晶学の方法論はすっかり様変わ りした、今では結晶さえ得られれば, 構造は決まったよ うなものだ．放射光施設で回折デー夕をとり，プログラ ムに通せば空間群も格子定数も, さらには電子密度や分 子骨格さえも得られてしまう. 当然ながら, 蛋白質結晶 学は, この現状に向かって一直線に進んできたのではな く, 埋もれてしまった多くの試行錯誤を踏み台にしてき た. 本稿では華々しい歴史に埋もれてしまいそうな断片 にも光をあてながら, その発展を振り返った。

技術の発展とともに一世を風靡した装置すら消えてい くのは致し方ない運命である. そのような装置の例を 1 つ挙げるなら, 躊踷なくプレセッションカメラを挙げた い(図2左)。プレセッションカメラは, 蛋白質結晶の格 子定数や空間群を決めるのに, また同形置換体を探すた めにも, 長い間, なくてはならない装置であった. 今では ほとんど使われていないだろう，全国に何台残っている か知らないが，ぜひとも後世に残して欲しいカメラであ る、プレセッションカメラは逆格子の形をそのまま見る ことができる. 可能なら, このカメラを使って晶系や空 間群を自分で決めてみるがいい. 例えば, 空間群 $P 2{ }_{1} 2_{1} 2_{1}$ の結晶の 0 層を撮れば, 点群 (ラウエ群) $\mathrm{mmm}$ に由来す る2つの鏡映面と, 2 種類の 21 らせんの消滅則が見える (図2右)．P4 $4_{1} 22$ の結晶の $(h k 0)$ 面には, 消滅則に加え て, 点群 $4 / \mathrm{mmm}$ の, 4 回軸と 2 種類の鏡映面がきれいに

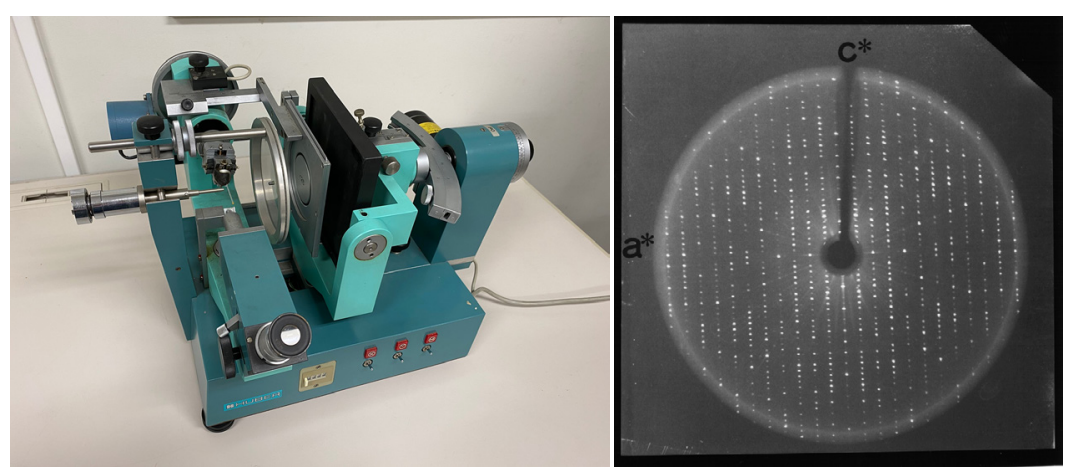

図2 プレセッションカメラとそれを利用して撮影した $(h o l)$ 面の回折写真 (空間群 $P 2{ }_{2} 2_{1} 2_{1}$ ). (A precession camera and a photo of ( $h 0 l)$ plane.) 
見える，逆格子や点群が，文字どおり，見えるのである。 私の場合はワイセンベルグカメラだったが, 4 年生のと きにそれを使って，あるぺプチド結晶の空間群 $P 41_{1} 2_{12}$ を 決定したときの達成感は今でも忘れられない，私にとっ て結晶学の最初の成果だったのだから。

\section{9. おわりに}

この分野で 50 年間研究を続けて, 現時点の技術で物 事の限界を決めてはいけないことを学習した，われわれ は1人で科学しているのではない. ほかの科学分野, さ らには科学者以外も含めた人類全体の英知で, 世の中は 発展していく. 自分が今日できないことが, 明日にはど こかで可能になるかもしれない，蛋白質結晶学の技術 も, 他分野の発展, 他分野のアイデアから生まれたもの がほとんどである、計算機, 放射光, 遺伝子工学, 情報処 理技術など，その例は枚挙にいとまがない. 日本の大学 の研究室の1つの大きな問題は，他分野との情報交換の 機会が少ないことにある、それもあって大学の研究室に 入ると, 学生の視野は, 途端に小さくなりがちである. 積極的に他分野にも興味をもち, 他分野の社会に溶け込 んで欲しい. そして, 必ず打開策が生まれることを信じ て, 未来に続く大きな研究に挑んで欲しい.
この 50 年間で技術は一変したが, 一方で, 文化や伝統 と呼ばれるものは, 世代が変わってもあまり大きく変わ らないことも学んだ. 50 年前, 欧米の進んだ科学は科学 雑誌でしか知ることができない時代, 欧米へ行って勉強 することは科学者になろうとする若者の夢だった。近 年, 外国に留学しようとする若者が減少しているという. 50 年前と異なり, 日本の大学の研究環境は欧米と肩を 並べている. インターネットが発達している時代, わざ わざ外国に行かなくても，情報の最先端にいることは可 能であろう。しかし, 他国の, 特に近代科学が生まれた 国の，文化や伝統を体験することは，我が国の科学を考 える上でお扔いに役立つと思う，日本の若者が，大志を もって世界に羽ばたき，世界をリードする日が来ること を願いながらこの稿を終える。

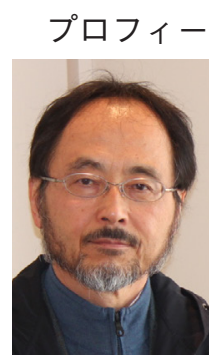

田中 勲 Isao TANAKA

北海道大学名誉教授

Professor Emeritus, Hokkaido University e-mail: tanaka@castor.sci.hokudai.ac.jp 専門分野: 蛋白質結晶学 